\title{
BETWEEN WORDS AND SILENCES: TRANSLATING FOR THE STAGE AND THE ENLARGEMENT OF PARADIGMS
}

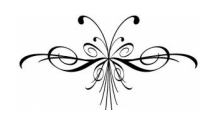

\author{
ALINNE BALDUÍNO P. FERNANDES
}

\begin{abstract}
This paper discusses the state-of-the-art of drama translation by contrasting traditional and contemporary practicebased approaches. Starting from some of the most prominent voices in Translation Studies (Bassnett 1984, 1988, 1991 and 1998) and moving to contemporary views (Johnston 1996 and 2010; Upton 2000; de Senna 2009), this study will demonstrate how Translation Studies currently offer insufficient resources to deal with the problems of translation for the stage. Translating for the stage presents problems that go far beyond the relationship between different language pairs as it deals with non-verbal systems that are created by and that create verbal signs, and as it is a work of art to be performed to potential audiences with cultural backgrounds different from that of the original play. Finally, it will provide a personal account of an ongoing drama translation project of Marina Carr's play By the Bog of Cats... (2005) into Brazilian Portuguese that I am carrying out in the light of a more creative and contemporary mindset.
\end{abstract}

Keywords: performability; drama translation; translation for the stage; audiences; non-verbal signs.

\section{Resumo}

Este artigo discute o estado da arte da tradução para o teatro por meio de uma análise que põe em confronto abordagens tradicionais e mais contemporâneas, que se baseiam na prática do teatro. Tomando por discussão inicial algumas das vozes mais influentes em Estudos da Tradução (Bassnett 1984, 1988, 1991 e 1998), em seguida, expõe vozes contemporâneas e procura, assim, demonstrar a insuficiência e a falta de recursos atualmente disponíveis nos Estudos da Tradução, como disciplina acadêmica, para lidar com os problemas da tradução para o palco. Essa atividade apresenta problemas que se situam muito além da relação entre diferentes pares linguísticos, uma vez que o texto teatral cria signos não verbais e lida com espectadores de diferentes culturas. Por fim, este artigo apresenta um breve relato pessoal de um trabalho em desenvolvimento que consiste em um projeto de tradução para o palco da peça By the Bog of Cats... (2005) da dramaturga Marina Carr para o português do Brasil à luz de um pensamento mais criativo e contemporâneo.

Palavras chave: performabilidade; tradução teatral; tradução para o palco; espectadores; signos não-verbais. 


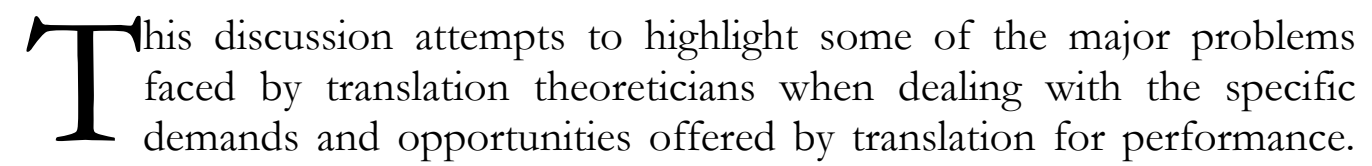
More specifically, it attempts to demonstrate how the discipline of Translation Studies alone does not offer a sufficiently flexible frame of reference or of discourse to account for the problems of theatre translation. In many ways, however, Translation Studies is still evolving. Translation Studies started in the nineteen-sixties as a branch of Linguistics, and, for several decades, it fought to assert itself as a linguistic discipline. In the nineteen-eighties, Translation Studies went through a cultural turn, which saw it beginning to move away from an exercise of comparing two or more different language pairs, and expanding its scope to explore the cultures involved in the production and reception of texts and translated texts. ${ }^{1}$ However, Translation Studies has until recently not been able or willing to engage and deal with the textual and metatheatrical problems of drama translation taken together. To demonstrate the inefficiency of the discipline in this area, I will refer to some of its most prominent voices, paying particular attention to the seminal works of Susan Bassnett (1984, 1988, 1991 and 1998). Then I will look at more contemporary approaches to drama translation that have begun to question the academic scope of Translation Studies as a discipline in its own right, but see it rather as an interdisciplinary field of study - a re-construction of the discipline that is supported by many practitioners. Finally, I will position my own work as a practitioner and theoretician of drama translation in the light of these conflicting approaches.

\section{Revisiting Some Exponential Voices in Drama Translation}

We should begin by exposing a contested notion in Translation Studies: performability, which, invariably, goes hand in hand with speakability and playability. ${ }^{2}$ These three lexemes are dealt with in Translation Studies as different names for the same problem - if, indeed, it is a problem at all. The standard reference book on translation theoretical traditions, the Routledge Encyclopaedia of Translation Studies (Baker 2001/2005), points out in the first paragraph under the entry "Drama translation" that one of the major problems of translated plays is their performability, which invariably compromises their relationship with their corresponding source texts. ${ }^{3}$ One

\footnotetext{
${ }^{1}$ From 1965 to 1975, discussions focused on notions of equivalence between different linguistic systems; in the late 1970s, discussions focused on historical aspects of translation theory; in the 1980s, discussions were heated by the cultural turn, which led to post-colonial and gender-based approaches to the study of Translation; and in the 1990s, discussions focused on the translator's visibility and the academic status of the discipline. For a more detailed account of the history of the discipline, see Snell-Hornby (2006).

2 Espasa (2000) lists some terms that are be interchangeable in the literature of drama translation: performability, playability, theatricality, theatre specificity and speakability.

3 "[G]reater demands are also placed on the translation [for the theatre] with respect to its 'performability', thus increasing the tension between the need to establish relationships between the target text and
} 
of the most prominent figures in Translation Studies, Susan Bassnett has been debating this issue over almost twenty years. The author's insistence on the importance of the verbal aspects of the translated playtext and its relationship to the original without bringing any further substantial development to the subject probably indicates that there is something fundamentally misplaced within this debate.

Bassnett (1984) declares that drama translation is a 'paradox'. The author says:

The two texts - written and performed - are coexistent and inseparable, and it is in this relationship that the paradox for the translator lies. The translator is effectively being asked to accomplish the impossible - to treat a written text that is part of a larger complex of sign systems, involving paralinguistic and kinesic features, as if it were a literary text, created solely for the page, to be read off that page. (ibid: 87 ).

The translator has to dissolve a connection of difficult solubility to the point that, if dissolved, as in a chemical reaction, its original state, that is that of a playtext, is changed into something else, in this case, a literary text. However, why should the translator treat the playtext as a literary artefact as opposed to treating it as a script encompassing "paralinguistic and kinesic features"? To put it succinctly: dealing with extratextual elements, such as the paralinguistic and kinesic features of the theatre, is beyond the scope of Translation Studies as interpreted and applied by Bassnett.

In attempting to systematise drama translation, Bassnett sets out five translation strategies, which may be read as five different ways of looking at a playscript. ${ }^{4}$ The first is to regard it as a "literary work"; the second is to use the source language's cultural context as a "frame text"; the third is to translate performability; the fourth is "to create SL [source language] verse drama in alternative forms"; and the fifth is "co-operative translation" (ibid: 90-91). As regards "performability", the author says that there is a wide range of opinions on the subject, but that no one ever defines it (Bassnett 1984: 90). The author adds that the term seems to imply the creation of "fluent speech rhythms and so produce a text that TL [target language] actors can speak without too much difficulty (at least in the opinion of the translator)" (ibid: 90-91). "Co-operative translation", which would seem to encompass performability, dismisses it: "This type of translation avoids the notion of

its source (the adequacy factor), and the need to formulate a text in the target language (the acceptability factor).” (Baker 2001/2005: 71, my italics).

4 The five strategies are spelt out here (following Bassnett 1984: 90-91): (1) to regard the theatre text as a "literary work" - according to Bassnett, it is the most common treatment given to a theatre text, where there is no concern with extratextual aspects, and the translator strives at remaining "faithful" to the original text; (2) to use the SL's cultural context as "frame text" - it involves the use of cliché and stereotypes of the source culture to generate a comic effect; (3) to translate "performability" - it is when translators take into account extratextual elements which compound the overall performance and produce a speakable text with "equivalent registers" in the TL; (4) to create "SL verse drama in alternative forms" - it is to render verses in alternative verse forms, especially those more commonly used in the TL; and (5) "co-operative translation" - it is when the translator works with SL and TL native speakers and/or with actors and/or director who know the SL.

Scientia Traductionis, $n .7,2010$ 
performability as a quality that can be added to the written text and involves the translator simultaneously in the written and oral versions of the text." (ibid: 91). "Cooperative translation" also implies the participation of a native speaker of the source language, which disregards any expertise on the part of the translator on the field $\mathrm{s} /$ he is translating. That is, the translator serves as a mere interlocutor that provides material for a director to make art out of this shapeless clay.

In favouring "co-operative translation" as the best strategy for drama translation, Bassnett argues that the translated playtext does not need to have potential for performance in itself, as the text will be redrafted by the director. In the co-operative approach, it is impossible to gather what the translator is supposed to do with the playtext. Not only does Bassnett confuse a concept that is already blurred, but she also seems to move back to strategy one: to treat the theatre text as a literary work. But why avoid translating with performance explicitly in mind?

In Bassnett's 1988 book Translation Studies, the author dedicates only one short section of the third chapter to "Translating Dramatic Texts", which is indicative of how little critical attention Translation Studies pays to this complex area. In this section, the author revisits the notion of performability, a term that remains troublesome. This time, the notion of performability is under the signifier playability. She says that when one translates with a view towards playability, the translator works keeping 'extra dimensions' in mind. However, the playtext remains ill-defined; she says that this type of translation is different from any other and that it "contains distinguishable structural features that make it performable beyond the stage directions themselves" (1988: 122). The playtext's exclusive features are never revealed, and, once again, the author falls short of clarifying any issues of drama translation.

In another article, Bassnett insists that performability is employed by those engaged in the business of staging a playtext to "describe the indescribable" (Bassnett 1991: 102). A performable text would also be related to "fluent speech rhythms in the target text" (Bassnett 1991: 102). However, to associate performance to "fluent speech rhythms" is still simplistic and narrow, in the sense that it is absurd to assume that a single style, even one characterised as fluent, could be solely pertinent to theatrical language. Therefore, she dismisses other forms of register or rhythms that reflect social and cultural practices evinced by the interplay between text and its physical realisation.

In 1998, Bassnett acknowledges the need for adopting a new approach to drama translation. Departing from the hermeneutic notion that a text may be read in multiple ways by its multiple readers, different readings allow for different interpretations on the part of the translator, the director, and the actors, which, in turn, allow for different possible performances of the same playtext ${ }^{5}$. That also applies to the fact that each time a translator ventures into the translation of a new play, s/he faces a new individual and almost exclusive case study. Here Bassnett

5 "It is generally accepted that the absence of theory in this area is connected to the nature of the playtext itself, which exists in a dialectical relationship with the performance of that same text." (Bassnett 1998: 90). 
concedes that traditional translation theory may indeed be deficient in its treatment of the actual problems of translating for the stage. It seems that translation theory, as approached by Bassnett, has prioritised the status of the text, focusing too much on the relationship with its source as opposed to considering any correspondence between the translated playtext and performance. After lingering for so long on the paradox of performability, Bassnett seems ready to acknowledge that one possible solution for this problem could be found by looking beyond the extant paradigms and models.

The problem of translating for the theatre is now viewed as much more context-based than it first appeared to Bassnett, who strove to find ideal circumstances under and according to which this type of translation should be undertaken. Once we realise that theatre translation contains such a rich universe so poorly explored - different languages, different linguistic codes; different cultures, different cultural codes; different theatres, different theatrical traditions; different audiences, different memories -, it is urgent that theoreticians start drawing attention to theatrical sign systems and audience expectations.

Although theorists such as Bassnett seem to be on the verge of declaring that the problem of performability is not a real one, this paper will argue that there are real questions that have been ignored in Translation Studies so far. Translating for the stage does present the translator with real problems in terms of making the target text performable, such as: depiction of location, idiolect, the interplay of verbal and nonverbal signs, extratextual and contextual references, and audience reception, to list just a few. When one translates for the stage, many questions have to be dealt with arising from the materiality of the theatre, especially of course the whole question of the context into which the play is to be translated. In other words, producing a script for performance can and should be discussed as a palpable issue.

A theorist who makes an important contribution to the performability of translated playtexts is Snell-Hornby (1997), who raises the issue of the extratextual aspects of drama translation. She discusses the non-verbal language of the theatre in terms of its function and of its relation to verbal language. The author, thus, classifies playtexts as multi-medial, as they have been crafted "to be spoken or sung", and, to a certain extent, they rely on "non-verbal forms of expression (graphic, acoustic and visual) for their full realization" (ibid: 188). The author explores the interplay between the verbal and non-verbal language of plays, noting that one of the functions of the theatrical verbal language is to trigger non-verbal action. In other words, in the theatre, verbal language is contingent upon and validated by non-verbal actions. She explains, through the lens of semiology, that there are three main types of non-verbal actions, or signs, that relate to and represent objects. They do it in terms of likeness, which are known in semiology as icons; spatio-temporality, known as indexes; and cultural conventions, known as symbols (ibid).

In this way, the author explains the relationship between non-verbal actions and spectatorship. Interpretation of non-verbal signs varies according to the spectators' prior knowledge of what they witness on stage. Iconic signs are interpreted in terms of where they stand in relation to the context of the play; 
indexical signs depend on the spectators' ability to associate, for instance, sounds to the objects they refer to, as in a metonymic relation; and symbolic signs depend on the spectators' familiarity with their meaning in the culture in question. However, it seems that, as well as symbolic signs, in some cases, indexical signs may also depend on the culture in which they are inserted. Whenever external variables are needed to decipher non-verbal signs, or better, whenever the world of the play itself does not provide enough information of non-verbal signs, the translator may need to act as a cultural mediator in making non-verbal signs explicit or, perhaps, domesticating them to the audience, that is, making domestic elements prevail over foreign ones in a way that seems natural to the target audience. ${ }^{6}$

Consequently, Snell-Hornby states that the performability of a playtext relies much on the potential of the verbal text "for generating nonverbal action and effects within its scope of interpretation as a system of theatrical signs." (ibid: 191). She enumerates three possible types of actions and effects that the verbal text may generate: paralinguistic features, which encompass vocal elements; kinesic features, which encompass "body elements, postures and gestures"; and proxemic features, which encompass the characters' movements on stage and the way they stand or move closer or further from one another (ibid: 190). After exposing this range of nonverbal elements and their systems, the author sees translation as the creation of "a new dramatic 'score' for a performance that is coherent and acceptable within the target culture.” (ibid: 195). To the author, as elsewhere stated in this discussion, the problem of many translated playtexts is that they tend to focus strictly on the verbal text, and they dismiss the interaction and interplay of verbal and non-verbal signs. To use Snell-Hornby's metaphor, performability is about creating a complete "music score", involving all its required music sheets, instruments and performers (cf. ibid: 187). ${ }^{7}$ What is interesting about Snell-Hornby's approach to drama translation is that, in referring to non-verbal signs in translation and in pointing out that the translated playtext should work according to its own "score", she moves towards the destigmatisation of the relationship between original and translated texts.

In sum, as pointed out and exemplified by Snell-Hornby, even though there has been a move towards a more complex approach to drama translation, there is still a gap between the performance of a translated play and the translated play itself. As seen in the works of Bassnett, her exponential discourse on drama translation tends to treat the playtext as a "literary text" and to ignore theatrical aspects. But there are new voices in theatre translation who are now arguing persuasively for translated plays to be seen as having the potential to create different types of theatre events.

\footnotetext{
${ }^{6}$ For a detailed discussion on foreignisation and domestication in translation see Venuti (1995).

7 Music score functions as an interesting metaphor for drama translation, but it still holds a sense of something that is performed systematically. There is a deeper sense of unpredictability in theatre in a way that nothing can guarantee that the same play, performed by the same actors and directed by the same director, will be performed in the same way for the second time. In this vein, O'Thomas (2009: 103) suggests jazz as a metaphor for drama translation and adaptation in face of "the key element of improvisation as [their] ontological force". The publication of this citation has been kindly permitted with Dr. Mark O'Thomas's agreement.
}

Scientia Traductionis, $n .7,2010$ 


\section{Expanding Paradigms: Voices of Practitioners}

In Translation Studies, the idea of performability seems to be problematic for two main reasons: first, it questions the validity of the overall "score" of the original play when transferring it to a different language, and urges for a thorough reshaping of the text, which, for some trends of Translation Studies, represents the distancing of the translated playtext in relation to its original. Second, performability requires from the translator knowledge of and skills for creating a text as a dramatist. Johnston (1996a) acknowledges the debate that the notion of performability has provoked in academic circles. Hence, he comes to terms with the subject matter preferring to abstain from defining the term performable, but he suggests that translators should try to find "a rhythmical solution that enables speakability and stylistic marking/ significance to co-exist." (ibid: 67). The author compares translating a play to writing one in the sense that a translated play should work, provoke, and engage as much as any good play (cf. ibid). He also argues that the translator is constantly dealing with some "doubleness" in his/her reading experience. This "doubleness" refers to the fact that the translator deals with the playtext as a piece produced in and to a specific culture, and, at the same time, $\mathrm{s} /$ he has to take into consideration how this piece can be received by another culture.

Most recent works on drama translation see the translated playtext as a work that is the result of a re-creation concerned with meeting the needs of a potential audience, and, it is, therefore, elaborated and shaped for such purpose. The improvisational nature of the genre presents a new challenge to the translator each time $\mathrm{s} / \mathrm{he}$ deals with a different play in a way that each play becomes a different casestudy, and hence the difficulty to set rules and to confine drama translation to a specific paradigm. ${ }^{8}$ The focus here is no longer on old linguistic concerns of prescriptive trends of Translation Studies, but on finding creative strategies to produce a translated playtext that is a work of art in its own right. The literature on contemporary approaches to drama translation reveals numerous case studies reporting different treatments given to playtexts prepared to suit specific audiences in different countries. Therefore, what is about to be put forward here are different case studies that reveal the contribution of some of these translators working under distinctive circumstances and for distinctive audiences. ${ }^{9}$

For example, de Senna (2009), translator of Sarah Kane's play Blasted (1995) into Brazilian Portuguese, speaks of his dilemma as to whether or not he should relocate the English play to Rio de Janeiro in his translation for a Carioca audience. He chooses to re-locate the play arguing that, as his objectives are to expose Rio's

\footnotetext{
8 Upton and Hale (2000: 12) say: "It is almost impossible not to suspect that one reason why performance translation has remained the poor relation of the translation world (at least as far as Translation Studies is concerned) is that translation theorists are generally unaware of the extent, richness and diversity of the theatrical tradition. Practicing theatre translators are, by and large, similarly unaware of translation theory."

9 This is observed in works such as Stages of Translation (edited by Johnston 1996b) and Moving Target (edited Upton 2000).
} 
scandalous civil violence by means of this play, he sees making it more explicit as his best option. Additionally, he defends the fact that this choice will serve to subvert the Brazilian upper bourgeoisie's motto that anything that comes from foreign lands, especially from Europe or the United States, is better and more sophisticated than what is produced domestically. ${ }^{10}$ In a sense, re-locating the play's setting to Brazil represents a political act of similar proportion as compared to the choice of translating this play itself.

Similarly, in thinking of a potential Irish audience, another case study of relocation is Irish playwright Brian Friel's “translation” of Chekhov's Three Sisters. Friel has created a version of Chekhov's Three Sisters based on five standard English translations from the Russian without speaking a word of that language. Friel, a great admirer of Chekhov, felt the need to produce a version that would sound more appealing to Irish audiences. In discussing his re-creation of Three Sisters, Friel argues that " $[\mathrm{t}]$ he ideal condition would be to have a playwright who was fluent in Russian. But if you have to forgo the one, it's better for the translator to be a dramatist. There are bigger truths beyond that of the literal translation." (Murray 1999: 100). From a scholarly point of view, according to the Encyclopaedia of Translation Studies, "literal translation" would refer to a word for word translation, which does not seem to be the case for the translations Friel refers to. When Friel speaks of "literal translation", he may be referring to translations that are merely linguistic, in the sense that they may read well and make sense, but they still lack something; something that could add more "colour" to their representation of the world. In spite of the multiple notions of "literal translation" possibly in play, Friel makes a crucial point when he asserts that it is "better for the translator to be a dramatist" (ibid). Some translators seem to forget that a translated play has to be performed as a piece of art in its own right.

The translated text not only travels from one language to another, but it may also travel from one place to another in terms of its imagined setting on stage. De Senna's and Friel's experiences reveal the fact that drama translation is contingent upon its performance, and therefore, the translated text is re-crafted in ways that go beyond words. In this vein, Cameron (2000), translator of Hélène Cixous's works into English, defends the notion that translations are not reflections of its original texts, but asymmetries. She translates Cixous in the light of Cixous's writing theory, which contributes to the understanding of Cixous's own work and insights on translation. Cameron observes that translation is a "transformation, from A to B. But A in Cixous does not equal B. As words in one language do not equal words in another." (ibid: 106). Cameron also compares the translator's task to that of the actor in relation to the playtext: just as the actor releases paralinguistic and proxemic meanings, which are not (explicitly) indicated in the playtext, the translator releases the potential of the original text into a new text. In this interplay, both translator and actor interpret and produce signs that are reinterpreted, in turn, by the spectator.

10 "Paradoxically, then, my domestication of the setting is foreignising, subverting the established dominant/ subaltern relationship by relocating the action to Brazil, not assuming the easy familiarity with the cultural referents of the metropolis." (de Senna 2009: 261).

Scientia Traductionis, n.7, 2010 
Along these lines, Upton and Hale (2000) point out some features that make the translated text asymmetric in relation to its original and some of the reasons why a translated playtext is necessarily asymmetric. Asymmetry can be read here as the fact that a translated play is not the exact reflection of its original, that is, it does not equal its original because it is crafted for a different purpose and for a different audience. This asymmetry may rely on the fact that a translated playtext deals with, among a myriad of issues, cultural representation. The translated playtext can easily foreignise or domesticate a play depending on the translator's choice of location, rhythm and cultural milieu ${ }^{11}$. The authors defend the notion that the translated playtext is the place "where the original is not distorted but deliberately recrafted to address the ultimately ephemeral moment in which it is to be performed" (Upton \& Hale 2000: 9). The ultimate objective of re-crafting a translated playtext in multiple recreative ways is undoubtedly to engage a potential audience with the performance. In order to ensure that the translated play functions in the way that a translated play can speaking of there, of the source culture, as well as of here, of the target culture -, the translator can and should play an active role in the production of the play - a role that is as important as the considering of issues of cultural transfer in the actual process of translating. This affirmation, in a way, refers back to Bassnett's concept of collaborative translation. However, the main difference lies in the fact that what I want to propose that the translator can undertake an active role in the overall production of the play, and that this active part refers to understanding the mechanisms of the theatre.

In the theatre, verbal language is only one element among the various elements that promote the encounter of two cultures. Therefore, instead of linguistic encounter, theatre translation could be described as cultural encounter. Upton and Hale add that "[c]ultural milieu is embodied in the specifics of any or all of the signifying elements (actors, physical appearance, gesture, set, costume, lighting, sound, kinesics, proxemics, etc), as well as in the spoken word." (ibid: 7). When taking into account the complexity of the elements involved in performance, one realises that not only the translator translates, but also the materiality of theatre where the translated play will be staged compulsorily takes part on this work of re-creation. In other words, more than bringing one world into another, a translated play, in this fusion of cultural elements, creates a new world.

Nevertheless, this re-creation is also an act that requires responsibility on the part of the translator. ${ }^{12} \mathrm{~A}$ translator may choose to dislocate elements in play, to bring them to the fore, to highlight them, or to shade them according to the purposes of the performance. In this vein, a translator is responsible for the representations that

\footnotetext{
${ }^{11}$ As, for instance, de Senna (2009) chose to domesticate the play to meet his audience's imagined needs.

12 In this respect, de Senna (2009: 258)'s re-located translation develops a peculiar sense of relationship with and responsibility in relation to its original: "I am tempted to go further and think of theatrical translation as an attempt to procreate a text, to couple it with a new performance environment so as to generate a new piece that bears a filial relation to the original (including my duty to honour it and of course a tendency to rebel against it), but has a life of its own and moves of its own accord."
} 
s/he creates. Such representations can - and arguably perhaps should - be located not in one context or another, the original or the receiving contexts, but within an imagined movement between those contexts. Johnston (2010) compares excessively located representation in drama translation to museological practices in the sense that the latter "have played a fundamental role in fabricating, maintaining and disseminating many of essentialist fictions that make up the social realities of the modern world." (ibid: 59). He explains this saying that museological exhibitions separate a special place for texts and artefacts where they create "a representational space", and "where they are inevitably infused with a sense of loss, experienced in terms of absolute alterity." (ibid). Therefore, drama translation is about ethics, as it is responsible for representing the other, for building or challenging essentialisms, in a way that translation can be interpreted as a site responsible for the representation of otherness, and, at the same time, for negotiating sameness and change.

Former drama professor, critic and translator Robert W. Corrigan provides an interesting insight for the design of a stage-language. In the nineteen-sixties, when translation was not even an academic discipline, his article starts discussing the novelty of European avant-garde theatre in the USA and its "mysterious hold" on North American sensibilities (Corrigan 1961: 95). Corrigan highlights the emphasis on gesture as opposed to the spoken word so much present in Ionesco's, Beckett's, Genet's, Adamov's, and Ghelderode's plays. This observation leads the author to ponder on the importance of movement on theatrical stage, in spite of the word.

However, Corrigan's appeal to gesture does not intend to demean the spoken word, or, in Snell-Hornby's terminology, the verbal sign system, but to shift its role. The author starts by criticising the way many scholars, at his time, classified the playtext as a branch of literature ${ }^{13}$, and forgot that, in principle, the playtext is $a$ performed text (Corrigan 1961: 96). It is worth to quote Corrigan's statement on the special nature of the language of this performed text, inspired by Antonin Artaud and his followers' view of the theatre:

\section{For them [the actors] the stage is a concrete physical place which must speak. its own language - a language that goes deeper than the spoken language, a language that speaks directly to our senses rather than primarily to the mind as with the language of words. (ibid: 96)}

This statement epitomises Corrigan's argument that a drama translator does not write primarily for readers, but he or she writes for actors - and, ultimately, through them, for a potential audience. And Corrigan does not differentiate (original) writers from translators; both, in his view, should write with the governing principle of moving words, and, thus, moving the audience. The author insists that the writer's/ translator's most important tool is the actor, as, in him, resides the

${ }^{13}$ As indeed, at his time, theatre was studied as a branch of literary studies. Corrigan was one of the founders of the School of the Arts (now Tisch School of the Arts) at NYU in the late nineteensixties. The foundation of Tisch was important for decoupling performing arts from literary studies at NYU.

Scientia Traductionis, $n .7,2010$ 
"emotional force" crucial to the theatre: the actor's ephemeral humanity metaphorically expressed in his even more ephemeral performance.

Therefore, the writer's/ translator's main resource to produce a performable script is the actor. Working with actors may be a valuable aid to understand that to write for the theatre is not only a matter of writing well, but it is also a matter of knowing when. It is to know the placing and timing of words combined with what the actors do. When the author speaks of this generation of movement provoked from words, and which produce words, what comes to mind is Stanislavski's ${ }^{14}$ concept of subtext - the action behind, between and in the words. The action, which produces feeling, which produces words, which, in turn, produces action. Similarly to Friel's observation, Corrigan summarises, "I feel very strongly that no one can translate for the theatre - just as no one can write for it - unless he knows what writing for the theatre is and how it differs from literature." (ibid: 100). Based on his personal experience of translating Chekhov's plays and directing his own translations, Corrigan urges that translators use actors to understand the primary principle of speakability, and what moves an audience (the how, the when, and the why of words).

Drama translation goes far beyond the translation of words. It is about communicating the whole world of the play, created exclusively for the theatre in a way that it provokes its spectators and transfers them to this other world. In face of this need for re-creation, Nagy (2000) raises an interesting point by asking if translation is really the best word to describe this exercise of "translating" for the theatre, and if there could be a better word to encompass this notion of going beyond words, of creating a new spectacle. ${ }^{15}$

\section{A Personal Account as a Practitioner}

A translator chooses to retell a story and chooses the way this story will be retold. However, when writing for the theatre, the translator is empowered and constrained by the requirements of a paying audience. These requirements provide opportunity for change and re-creation, and, at the same time, they restrict and narrow the possibilities according to the demands and expectations of a potential audience. Prescriptive translation theoreticians have fought to explain drama

${ }^{14}$ In the late nineteen-twenties, Stanislavski proposed a system to train actors. This system is based on the idea that actors's physical actions are contingent upon their characters' is inner life. To make it short, Stanislavski's system relies on psychophysical techniques where all physical action is derived from emotion and thought. The subtext is one of the elements that compound this psychophysical system, and it refers to the meaning lying underneath the action or utterance. For a more detailed account of Stanislavski's system, refer to Stanislavski (2008).

15 "I wonder whether translation is really the best word to describe everything that is involved where translating and theatre are concerned. But is there any better word to express what happens to a text when it is changed to suit different needs?" (Nagy 2000: 151).

Scientia Traductionis, n.7, 2010 
translation in terms of rigid categories while the most enlightening contributions have come from those involved in the theatre.

The views of contemporary drama theoreticians and practitioners as well as Corrigan's confirm the void that until comparatively recently has existed in translation theory when it comes to thinking and doing drama translation. As exposed in the first section of this article, when considering the theoretical trends prescribed by Bassnett, Translation Studies has looked at drama from the point of view of Corrigan's contemporary colleagues, who levelled the theatre with the experience of translating literature, words on paper, words to be read, and, therefore, to be interpreted as such. Of course, one can scrutinise the theatre through the lenses of literature (or linguistics), but this is an oversimplification of the subject.

While translating my first draft of what was at first No Pântano dos Gatos..., which soon became Era uma vę̧, no Pântano dos Gatos..., I found myself so reluctant to let go the formalities of register and the worries of rendering the ideas encapsulated in the verbal language of By the Bog of Cats... My translation journey started out from a prescriptive Translation Studies mindset: I first translated the play with an illusionary surgical precision, looking for categories and patterns in the verbal signs of the play. I employed a formal register as I struggled with the conservative thought that those words had to read right. Barely did I know I was tiptoeing on muddy terrain, a bog, to put it symbolically, especially in misty weather. Monica Murray's emblematic line in the first act of the play epitomises the atmosphere of the play, and, to create a metaphor, the atmosphere of the realms where the foreign translator's journey takes place: 'but ya know this auld bog, always shiftin' and changin' and coddin' the eye' (Carr 2005: 267). This journey revealed the insufficiency of my categories in enabling me to engender a more complex understanding of this peculiar place and its peculiar inhabitants. On the level of verbal signs, I realised that language should portray a tone that resonates with the countryside, where echoes of a forgotten place could be overheard. This realisation led me to the first substantial change in my translation: the characters should speak in a dry and guttural tone, as if they were masticating words. Thus, along with the writing of the second draft, there came the creation of a new world; a new world which attempts to depict the Irish rural Midlands in a tone that could be associated to the sound of Brazilian dry-lands, not only present in the language of the Northeast of that country, but also in the Midwest, in the vicinity of the Brazilian delicately planned capital city, and in pockets of dry-lands in the South of the country. This work-in-progress language still needs to be experimented with actors, and, invariably, to be re-drafted as many times as needed for performance. This experience led me from a conservative point of view, which I here refer to as the one still adopted by prescriptive theoreticians in Translation Studies, to subscribe to a practice-based one, which I refer to as the contemporary approaches to drama translation.

To round off this discussion, I would like to propose a working definition for a concept much discussed throughout this article: performability. To translate performability may be interpreted as to translate a playtext with a view towards making it speakable to actors, and shaping language in a way that entices its audience into the 
here and now of the performance. Indeed, I am applying speakability as a concept that is part of performability, but not as its synonym. Speakability implies producing a text to be spoken by actors. Performability encompasses and goes beyond speakability in the sense that it is concerned with both actors and audience. The method that informs the development of this stage language necessarily involves the participation of actors and director, which makes it, therefore, co-operative. However, differently from Bassnett's conceptualisation of the task, I want to suggest co-operation as a method to obtain a performable script. Additionally, I want to propose that the translator should be empowered and have more authority in his/her relation with the theatrical group. That is to say, differently from Bassnett's definition of co-operative translation that implies that the translator provides a gist for the director, and s/he creates a playscript out of it, I want to propose that the translator can and should actively engage with making theatre. S/he can be a very useful resource to the theatre group. The whole business of theatre is a co-operative enterprise; consequently translating for it could not be any different. This reflection is by no means conclusive; it is being improved and further developed in my current thesis investigation.

Alinne Balduino P. Fernandes Queen's University of Belfast alinnef@gmail.com 


\section{References}

BAKER, Mona (ed), Routledge Encyclopaedia of Translation Studies (London: Routledge, 2001/2005).

BASSNETT, Susan, Ways through the labyrinth: strategies and methods for translating theatre texts', in Theo Hermans (ed.) The manipulation of literature: studies in literary translation (New York: St. Martin Press, 1984, pp. 87-102).

132).

, Translation Studies (London \& New York: Routledge, 1988: 120-

, 'Translating for the Theatre: the Case Against Performability', in

TTR: Traduction, Terminologie, Rédaction, vol. 4, nº 1 (Montréal: Association Canadienne de Traductologie, 1991: 99-111).

, 'Still Trapped in the Labyrinth: Further Reflections on Translation and Theatre' in Susan Bassnett \& André Lefevere (ed), Constructing Cultures: Essays on Literary Translation (Clevedon/ Philadelphia/ Toronto/ Sydney/ Johannesburg: Multilingual Matters, 1998: 90-108).

CAMERON, Kate, 'Performing Voices: Translation and Hélène Cixous' in CaroleAnne Upton (ed), Moving Target: Theatre Translation and Cultural Relocation (Manchester, UK \& Northampton, MA: St Jerome Publishing, 2000: 101-112).

CARR, Marina, Marina Carr: Plays 1 - Low in the Dark, The Mai, Portia Coughlan, By the Bog of Cats... (London: Faber and Faber, 2005).

CORRIGAN, Robert W., 'Translating for Actors' in The Craft and the Context of Translation, William Arrowsmith \& Roger Sattuck (ed) (Austin, Texas: The University of Texas Press, 1961).

De SENNA, Pedro, 'This Blasted Translation: Or Location, Dislocation, Relocation' in Journal of Adaptation in Film \& Performance, vol. 2 n. 3 (Bristol: Intellect Books, 2009: 255-265).

ESPASA, Eva, 'Performability in Translation: Speakability? Playability? Or just Saleability?' in Carole-Anne Upton (ed), Moving Target: Theatre Translation and Cultural Relocation (Manchester, UK \& Northampton, MA: St Jerome Publishing, 2000: 49-62).

FRAYN, Michael (trans), Chekhov Plays: The Seagull, Uncle Vanya, Three Sisters, The Cherry Orchard and Four Vaudevilles, Anton Chekhov (London: Methuen Drama, 1988/2000). 
JOHNSTON, David (ed), Stages of Translation: Interviews and Essays on Translating for the Stage (Bath: Absolute Press, 1996a).

, 'Text and Ideotext: Translation and Adaptation for the Stage', in Malcom Coulthard and Patricia Anne Odber de Baubeta (ed), The Knowledges of the Translator: From Literary Interpretation to Macbine Classification (Lewiston, Queenston, and Lampeter: The Edwin Mellen Press, 1996b: 243-258).

, 'Metaphor and Metonymy: The Translator-Practitioner's Visibility', in Roger Baines et al. (ed), Staging Translation: Text and Theatre (London: Palgrave Macmillan, 2010, forthcoming).

MURRAY, Christopher (ed), Brian Friel: Essays, Diaries, Interviews (1964-1999) (London: Faber \& Faber, 1999).

NAGY, András, 'A Samovar is a Samovar is a Samovar: Hopes and Failures of the Author as the Object and Subject of Translation' in Carole-Anne Upton (ed) Moving Target: Theatre Translation and Cultural Relocation (Manchester, UK \& Northampton, MA: St Jerome Publishing, 2000: 151-158).

O’THOMAS, Mark, 'Between Theory and Practice - Rethinking the Roles of Translator and Adapter in and through Contemporary Theatre Practice' (Unpublished Doctoral Thesis, Lancaster University, June 2009).

SNELL-HORNBY, Mary, 'Is This a Dagger Which I see Before me? The non-verbal language of drama' in Fernando Poyatos (ed), Nonverbal Communication and Translation (London: John Benjamins Publishing, 1997: 187-202).

, The Turns of Translation Studies: New Paradigms or Shifting

Viewpoints? (Amsterdam/ Philadelphia: Johns Benjamins Publishing, 2006).

STANISLAVSKI, Constantin, An Actor Prepares, Hapgoods, Elizabeth R. (trans.) (London: Methuen, 2008).

UPTON, Carole-Anne and Hale, Terry, 'Introduction' in Carole-Anne Upton (ed) Moving Target: Theatre Translation and Cultural Relocation (Manchester, UK \& Northampton, MA: St Jerome Publishing, 2000: 1-13).

VENUTI, Lawrence, The Translator's Invisibility (London/ New York: Routledge, 1995). 